\title{
The comparison of analgesic efficacy between ultrasound-guided continuous thoracic paravertebral block and continuous thoracic epidural block using bupivacaine - fentanyl in patients undergoing lung surgery: A prospective, randomized, controlled trial
}

\author{
Tran Thanh Trung' (D), Dang Van Khoa' (D), Trinh Van Dong² (D) \\ 1 Department of Anesthesiology - Resuscitation, 74 Central Hospital, Vinh Phuc, Vietnam \\ ${ }^{2}$ Department of Anesthesiology - Resuscitation, Viet Duc University Hospital, Hanoi, Vietnam
}

\begin{abstract}
Objective: This study aimed to compare the efficacy and the safety of ultrasound-guided continuous thoracic paravertebral block (CTPB) to the continuous thoracic epidural block (CTEB) for pain relief in patients undergoing lung surgery.

Material and Methods: Our study included 102 patients after lung surgery at the 74 Central Hospital from 9/2013 to 12/2017. Patients were divided into 2 groups: CTPB group $(n=51)$ and CTEB group $(n=51)$. The primary outcomes were the Visual Analogue Scale (VAS) scores when patients were at rest $\left(\mathrm{V}_{\mathrm{R}}\right)$ and movement $\left(\mathrm{V}_{\mathrm{M}}\right)$, the total used dosage of bupivacaine - fentanyl after surgery, plasma glucose, and cortisol levels, additional doses of morphine. Adverse reactions were recorded during the study. The study was approved by the Ethics Committee of the 74 Central Hospital. All participants provided their informed consent.

Results: There were no significant differences between CTPB and CTEB groups in terms of the $V_{R}$ and the $V_{M^{\prime}}$ total used doses of bupivacaine - fentanyl after 72 -hours of surgery ( $p>0.05)$, the increased plasma glucose, and plasma cortisol ( $p>0.05)$, and the additional doses of morphine. The percent of patients in the CTPB group undergoing adverse reactions in the circular system and the respiratory system was lower than in the CTEB group. Adverse reactions included vascular puncture, urinary retention, and itch.
\end{abstract}

Conclusion: Ultrasound-guided CTPB is an effective intervention of pain relief after lung surgery. Its analgesic efficacy is comparable to CTEB. Also, this method had fewer adverse reactions in circulation and respiration compared to the CTEB.

Keywords: Paravertebral block, analgesia, lung surgery, epidural block, postoperative pain

Cite this article as: Trung TT, Khoa DV, Dong TV. The comparison of analgesic efficacy between ultrasound-guided continuous thoracic paravertebral block and continuous thoracic epidural block using bupivacaine - fentanyl in patients undergoing lung surgery: A prospective, randomized, controlled trial. Turk J Surg 2021; 37 (3): 232-241.

Corresponding Author

Tran Thanh Trung

E-mail: trungdttc@gmail.com

Received: 19.10 .2020

Accepted: 04.04 .2021

Available Online Date: 28.09 .2021

@ Copyright 2021 by Turkish Surgical Society Available online at www.turkjsurg.com

DOI: $10.47717 /$ turkjsurg.2021.5053

\section{INTRODUCTION}

Lung surgery includes the removal of a lung, lobes of a lung, bronchopulmonary segments, or any part of the lung, or lung decortication. Lung surgery affects the circular and respiratory systems that are essential organs in the body, leading to dangerous complications. Pain causes shallow breathing and limited cough resulting in the impairments of respiratory functions, the stagnation of secretions, collapsed lung, hypoxemia, hypercapnia, and respiratory failure. They increase the risk of the reintubation of the endotracheal tube and seriously affect the patients' mental health. Taken them together, pain relief for patients after lung surgery is essential for their recovery of regular movements and their satisfaction $(1,2)$.

There is a variety of studied treatments to reduce pain after general surgery or lung surgery including pain prophylaxis before surgery, additional treatments of morphine analogues or non-steroids anti-inflammatory drugs (NSAIDs), or nerve block. Currently, there are two latest pain management technologies, including patient-controlled analgesia (PCA) and continuous catheter-infused anesthetic into the epidural space, operative locations, and the plexus. Amongst them, thoracic epidural block (TEP) is possibly the most optimal technique for pain management after cardiothoracic surgeries. Nevertheless, this technique is contraindicated for patients having coagulopathy. It also leads to some adverse reactions, namely hypotension and injured nerves $(1,3,4)$. 
Recently, thoracic paravertebral block (TPB) is likely to be accepted for the replacement of TEB which is commonly a "golden standard" for pain management after cardiothoracic surgeries. Some advantages of TPB are the similar efficacy to relieve pain compared to TEB, a low rate of complications and a success higher rate supported by ultrasound. These features make TPB more appealing to clinical practitioners, and they need more evidence to reinforce the potential of the alternative method in various surgeries.

A disadvantage of preliminary TPB is the difficulty in the determination of loss-of-resistance and the "pop" feeling, and the detection of anatomical points. In recent decades, people have used ultrasound when applying TPB. The results have indicated that the technique helps practitioners realize the anatomical points, the directions of the needle, and the spread of the anesthetic $(5,6)$. Therefore, ultrasound-guided TPB is attracting anesthesiologists and is increasingly applied. However, each technique has its benefits and disadvantages (7-9).

Over the world, there is an increase in studies relating to TPB. However, these studies have reported inconsistent method, and various results are still debated (10). In Vietnam, there are only several studies relating to the TPB. Also, there is no study of the continuous thoracic paravertebral block (CTPB) as well as the application of ultrasound in pain management after lung surgeries. Thus, we conducted this study with the aim of comparing the analgesic efficacy after lung surgery between the ultrasound-guided CTPB and the continuous thoracic epidural block (CTEB) using $0.125 \%$ bupivacaine - fentanyl $2 \mu \mathrm{g} / \mathrm{mL}$ and evaluating the undesirable effects caused by these treatments.

\section{MATERIAL and METHODS}

\section{Study Design}

This is a prospective, parallel randomized (1:1), controlled clinical trial. The study report followed CONSORT guideline (Table S1).

The sample size of each group was calculated by the following formula previously reported (11), for the continuous variables and two controlled equivalent groups as follows:

$\mathrm{n}=\frac{2 \mathrm{C}}{(E S)^{2}}$, where:

C: determined from $a$ and $\beta$ (the probability that a test statistic giving $p<0.05$ )

For the null hypothesis, we chose $a=0.05$. For the alternative hypothesis, we chose $\beta=0.1$. The constant $C$ corresponding to the $\alpha$ and $\beta$ values retrieved from a standard table was $=10.5$. We chose the significant difference of Visual Analogue Scale (VAS) at rest between two groups by $0.59(p=0.104)$ with standard deviation $=0.91$, followed the report of Sagiroglu et al. (12).
Therefore, we had ES $=0.648$. The sample size of each group was estimated at 50.1. Finally, we recruited 51 patients in each group.

The participants who met the selection criteria were randomly divided into two groups, by the simple random sampling method using function RAND in excel. The random allocation sequence was conducted by an author who did not participate in the surgical procedure. Patients were divided into two groups, receiving postoperative analgesic regimen of bupivacaine $0.125 \%$ - fentanyl $2 \mu \mathrm{g} / \mathrm{mL}$ via either ultrasound-guided CTPB $(n=51)$ or CTEB $(n=51)$.

The science and ethics committee of biomedical studies of 74 Central Hospital approved this study (No. 458/GCN-BV74TW). All patients provided their written informed consent before being included in this study. The study was concordant with the Declaration of Helsinki.

\section{Patients Selection}

The study was performed at the 74 Central Hospital, from 09/2013 to 12/2017, for patients who received postoperative analgesic regimen after lung surgery or lung decortication.

The inclusion criteria were patients who underwent elective lung surgery opening one-side, age $\geq 16$, agreed to cooperate with the physicians for the postoperative analgesic regimen, and American Society of Anesthesiologist (ASA) class I, II (13). We excluded patients who disagreed to join the study, historically had an allergy to anesthetic drugs, currently had psychological problems, or had a local infection at the operation site. Data of the patients were excluded from our analysis if patients had postoperative complications, were on a ventilator after surgery $>4$ hours, needed the reoperation, or wanted to discontinue the study.

\section{Procedures}

Patients were examined and explained the protocol before the anesthesia as the standard. All patients in this study were anesthetized with endotracheal intubation following a standard guideline using midazolam $0.04 \mathrm{mg} / \mathrm{kg}$, fentanyl $3 \mu \mathrm{g} / \mathrm{kg}$, followed by propofol $2 \mathrm{mg} / \mathrm{kg}$ and rocuronium $0.8 \mathrm{mg} / \mathrm{kg}$, intubated with the suitable endobronchial tube, maintained with a closed circuit and low flow systems using isoflurane. Doses of analgesic medicines and isoflurane were adjusted by the scores of systolic blood pressure (P), heart rate (R), sweating (S), tear (T) which were previously reported (13). When PRST $\geq 3$, an additional intravenous injection of fentanyl $50 \mu \mathrm{g}$ was required. The relaxant medicine $0.2 \mathrm{mg} / \mathrm{kg}$ rocuronium repeatedly injected if train-of-four (TOF) $\geq 2$ (appeared the second response chain of adductor pollicis muscle) to ensure complete muscle relaxation.

After dermatomal block distribution, the ultrasound-guided CTPB or CTEB procedure was performed. We used the transduc- 
Table S1. Consort checklist of the study's report

\begin{tabular}{|c|c|c|c|}
\hline Section/Topic & Item No & Checklist item & $\begin{array}{l}\text { Reported } \\
\text { on page No }\end{array}$ \\
\hline \multirow[t]{2}{*}{ Title and abstract } & $1 \mathrm{a}$ & Identification as a randomized trial in the title & 1 \\
\hline & $1 \mathrm{~b}$ & Structured summary of trial design, methods, results, and conclusions & 1 \\
\hline \multicolumn{4}{|l|}{ Introduction } \\
\hline \multirow{2}{*}{$\begin{array}{l}\text { Background and objec- } \\
\text { tives }\end{array}$} & $2 a$ & Scientific background and explanation of rational & $2-3$ \\
\hline & $2 b$ & Specific objectives or hypotheses & 3 \\
\hline \multicolumn{4}{|l|}{ Methods } \\
\hline \multirow[t]{2}{*}{ Trial design } & $3 a$ & Description of trial design (such as parallel, factorial) including allocation ratio & 3 \\
\hline & $3 b$ & $\begin{array}{l}\text { Important changes to methods after trial commencement (such as eligibility } \\
\text { criteria), with reasons }\end{array}$ & Not applied \\
\hline \multirow[t]{2}{*}{ Participants } & $4 a$ & Eligibility criteria for participants & 4 \\
\hline & $4 b$ & Settings and locations where the data were collected & 4 \\
\hline Interventions & 5 & $\begin{array}{l}\text { The interventions for each group with sufficient details to allow replication, inclu- } \\
\text { ding how and when they were actually administered }\end{array}$ & 5 \\
\hline \multirow[t]{2}{*}{ Outcomes } & $6 a$ & $\begin{array}{l}\text { Completely defined pre-specified primary and secondary outcome measures, } \\
\text { including how and when they were assessed }\end{array}$ & 6 \\
\hline & $6 b$ & Any changes to trial outcomes after the trial commenced, with reasons & Not applied \\
\hline \multirow[t]{2}{*}{ Sample size } & $7 a$ & How sample size was determined & $3-4$ \\
\hline & $7 b$ & When applicable, explanation of any interim analyses and stopping guidelines & Not applied \\
\hline \multicolumn{4}{|l|}{ Randomization } \\
\hline \multirow[t]{2}{*}{ Sequence generation } & $8 a$ & Method used to generate the random allocation sequence & 4 \\
\hline & $8 b$ & Type of randomization; details of any restriction (such as blocking and block size) & Not applied \\
\hline $\begin{array}{l}\text { Allocation concealment } \\
\text { mechanism }\end{array}$ & 9 & $\begin{array}{l}\text { Mechanism used to implement the random allocation sequence (such as } \\
\text { sequentially numbered containers), describing any steps taken to conceal the } \\
\text { sequence until interventions were assigned }\end{array}$ & 4 \\
\hline Implementation & 10 & $\begin{array}{l}\text { Who generated the random allocation sequence, who enrolled participants, and } \\
\text { who assigned participants to interventions. }\end{array}$ & 4 \\
\hline Blinding & $11 a$ & $\begin{array}{l}\text { If done, who was blinded after assignment to interventions (for example, partici- } \\
\text { pants, care providers, those assessing outcomes) and how }\end{array}$ & Not applied \\
\hline \multirow[t]{2}{*}{ Statistical methods } & $12 \mathrm{a}$ & $\begin{array}{l}\text { Statistical methods used to compare groups for primary and secondary outco- } \\
\text { mes }\end{array}$ & $6-7$ \\
\hline & $12 b$ & $\begin{array}{l}\text { Methods for additional analyses, such as subgroup analyses and adjusted analy- } \\
\text { ses }\end{array}$ & Not applied \\
\hline \multicolumn{4}{|l|}{ Results } \\
\hline \multirow[t]{2}{*}{$\begin{array}{l}\text { Participant flow (a } \\
\text { diagram is strongly } \\
\text { recommended) }\end{array}$} & $13 a$ & $\begin{array}{l}\text { For each group, the numbers of participants who were randomly assigned, recei- } \\
\text { ved intended treatment, and were analyzed for the primary outcome }\end{array}$ & 7 \\
\hline & $13 b$ & For each group, losses and exclusions after randomization, together with reasons & Not applied \\
\hline \multirow[t]{2}{*}{ Recruitment } & $14 a$ & Dates defining the periods of recruitment and follow-up & 7 \\
\hline & $14 b$ & Why the trial ended or was stopped & Not applied \\
\hline \multirow{2}{*}{$\begin{array}{l}\text { Baseline data } \\
\text { Numbers analysed }\end{array}$} & 15 & A table showing baseline demographic and clinical characteristics for each group & Table 1 \\
\hline & 16 & $\begin{array}{l}\text { For each group, number of participants (denominator) included in each analysis } \\
\text { and whether the analysis was by original assigned groups }\end{array}$ & 7 \\
\hline
\end{tabular}


Table S1. Consort checklist of the study's report (continued)

\begin{tabular}{|l|l|l|l|}
\hline \multirow{2}{*}{ Section/Topic } & Item No & Checklist item & $\begin{array}{l}\text { Reported } \\
\text { on page No }\end{array}$ \\
\hline $\begin{array}{l}\text { Outcomes and estima- } \\
\text { tion }\end{array}$ & $17 \mathrm{a}$ & $\begin{array}{l}\text { For each primary and secondary outcome, results for each group, and the estima- } \\
\text { ted effect size and its precision (such as 95\% confidence interval) }\end{array}$ & $7-9$ \\
\cline { 2 - 5 } & $17 \mathrm{~b}$ & $\begin{array}{l}\text { For binary outcomes, presentation of both absolute and relative effect sizes is } \\
\text { recommended }\end{array}$ & Not applied \\
\hline Ancillary analyses & 18 & $\begin{array}{l}\text { Results of any other analyses performed, including subgroup analyses and adjus- } \\
\text { ted analyses, distinguishing } \\
\text { pre-specified from exploratory }\end{array}$ & Not applied \\
\hline Harms & 19 & All important harms or unintended effects in each group & 9 \\
\hline Discussion & 20 & $\begin{array}{l}\text { Trial limitations, addressing sources of potential bias, imprecision, and, if relevant, } \\
\text { multiplicity of analyses }\end{array}$ & $13-14$ \\
\hline Limitations & 21 & Generalizability (external validity, applicability) of the trial findings & Not applied \\
\cline { 2 - 5 } Generalizability \\
Interpretation
\end{tabular}

er of a high-frequency ultrasound transducer linear array (frequencies of 8-15 $\mathrm{MHz}$ ) to detect thoracic paravertebral space. A needle (Tuohy 18G) was inserted into this space. In the CTPB group, we put a catheter into the thoracic paravertebral space $2-6 \mathrm{~cm}$ of depth towards the top of patients. Meanwhile, a catheter thoracic epidural was put for the CTEB group using the loss-of-resistance technique. The locations where the transducer was put (T4-5, T5-6, or T7-8) were accordant to the locations of the incision.

Pain management after surgery was conducted if the patients were conscious, removed the endotracheal tube, had a heart rate of 60-90 beats/minute, maximal systolic blood pressure 90-140 mmHg, SpO $2 \geq 92 \%$, and VAS score $\geq 4$. Patients were given a mixture of $0.125 \%$ bupivacaine and fentanyl $2 \mu \mathrm{g} /$ $\mathrm{mL}$, prepared by $0.5 \%$ bupivacaine hydrochloride (Laboratoire Aguettant, France) and 5\% fentanyl (Rotex, Germany), through a catheter. A load-dose of the mixture was given, then a continuous infusion started with the concentration of $0.1 \mathrm{~mL} / \mathrm{kg} / \mathrm{hour}$ for the first 24-hours, $0.09 \mathrm{~mL} / \mathrm{kg} /$ hour for the second 24-hours, and $0.08 \mathrm{~mL} / \mathrm{kg} / \mathrm{h}$ during 48-72-hours after the surgery.

If pain relief was poor or ineffective, an additional PCA intravenous morphine was given, set as following : bolus $1 \mathrm{mg} /$ $\mathrm{mL}$, lockout time : 15 minutes, maintain dose: not applicable, 4-hours dose limit: 10 mg. The catheter was removed when we recorded data 72 hours after the analgesic regimen. If the patients had persistent pain after the catheter removal, PCA intravenous morphine was continued as presented above.

\section{Study Outcomes and Measurements}

Our primary outcomes included the VAS score at the rest $\left(V_{R}\right)$ and VAS score at the movement (VM), at 0-, 15-, 30-minutes, and 1-, 2-, 4-, 6-, 12-, 24-, 48-, 72-hours after the analgesic regimen; the additional consumption of morphine in the case patients ordered it to reduce their pain; the consumption of $0.125 \%$ bupivacaine - fentanyl $2 \mu \mathrm{g} / \mathrm{mL}$; the levels of blood glucose and cortisol before the surgery, before the pain regimen, at day-1, day-2, day-3 after the surgery; the forced vital capacity (FVC), the forced expiratory volume in one second $\left(\mathrm{FEV}_{1}\right)$ and the peak expiratory flow (PEF) before the surgery, at the day-1, day2, day-3 after the surgery. VAS score at rest was defined as the VAS score measured when patients relaxed. VAS score at the movement was defined as the VAS score measured when the patients coughed. The second outcome was the undesirable effects relating to the anesthetic technique, anesthetic medicines, and morphine analogues.

VAS score was assessed to measure the pain degrees of patients. Patients chose the best suitable images for their pain which were concordant with numeric pain degrees, where $0=$ no pain, $1-3=$ mild pain, $4-6=$ moderate pain, $7-8=$ severe pain, $9-10=$ worst pain.

\section{Statistical Analysis}

The collected data was analyzed using SPSS software (version 16, SPSS Inc., USA). The quantitative variables are expressed as mean \pm SD. The categorical variables were expressed as percent 
(\%). The differences of categorical variables by groups were assessed by $\chi 2$. The means of quantitative variables between before and after the intervention across each group were compared by paired student's t-test. The differences in means between the two groups were analyzed by independent student's t-test. The differences were statistical significance if $p<0.05$.

\section{RESULTS}

The study was performed from 09/2013 to 12/2017. The patients in this study were enrolled as shown in Figure 1. No patients dropped out of our study. Data of all patients were included in the analysis. The characteristics relating to gender, average ages, height, weight, body mass index (BMI), and ASA score were insignificantly different ( $p>0.05$ ) (Table 1).

In our study, we saw insignificant differences of surgical procedure $(p=0.687)$, incision ( $p=0.084)$, length of surgical skin incision $(p=0.851)$, total dose of bupivacaine $(p=0.356)$ and fentanyl between the two groups ( $p=0.356)$ (Table 2). Over half of patients in each group underwent lung decortication $(56.9 \%$ and $60.8 \%$ in the CTEB group and CTPB group, respectively). Lateral thoracotomy was more popular, with $98 \%$ in the CTEB group and $88.2 \%$ in the CTPB group.

After surgery, patients in both groups mainly suffered from moderate pain with the $V_{R}$ at the 0 -hour by $6.9 \pm 1.4$ and $6.5 \pm$ 1.2 , in the CTPB group and CTEB group, respectively. When they had any movement, the pain level was severe with the $V_{M}$ at this time point in the CTPB group and CTEB group by $8.0 \pm 1.2$ and $7.8 \pm 1.1$, respectively. After 15 minutes of the pain relief regime, $V_{R}$ strongly decreased from $6.9 \pm 1.4$ to $3.5 \pm 1.0$ in the CTPB group, and from $6.5 \pm 1.2$ to $3.5 \pm 0.9$ in the CTEB group. Similarly, patients only suffered from moderate pain instead of severe pain after 15 minutes of the regime when they had movements $\left(V_{R}\right.$ were $4.8 \pm 0.9$ and $\left.4.4 \pm 0.9\right)$. The pain levels steadily reduced across time points in both groups when they were at rest or movement. Patients only had mild pain at 72-hours after the regime in both groups. VAS scores between the two groups were not statistically different at each time point (Table 3).

The percent of patients who additionally needed PCA intravenous morphine after their surgery was $19.6 \%$ and $13.7 \%$ in the CTPB group and CTEB group, respectively, which were also not statistically different ( $p>0.05$ ). The total dose of morphine consumed by patients during 72 hours after surgery was $10.1 \pm$ $6.6 \mathrm{mg}$ (CTPB group) and $8.7 \pm 5.2 \mathrm{mg}$ (CTEB group). There was a similarity of the times patients asked for PCA (13.9 \pm 8.0 vs $14.4 \pm 5.1)$ and the times of no pain relief control between two groups (3.8 \pm 2.6 vs $5.7 \pm 3.6)$.

Before the surgery, blood glucose level was not different between the two groups $(p=0.410)$. These levels hit a peak in both groups, by $8.5 \pm 2.2 \mathrm{mmol} / \mathrm{l}$ and $8.5 \pm 3.0 \mathrm{mmol} / \mathrm{l}$ before the analgesic regime, then gradually decreased afterward. However, blood glucose level of patients in the CTEB group returned to

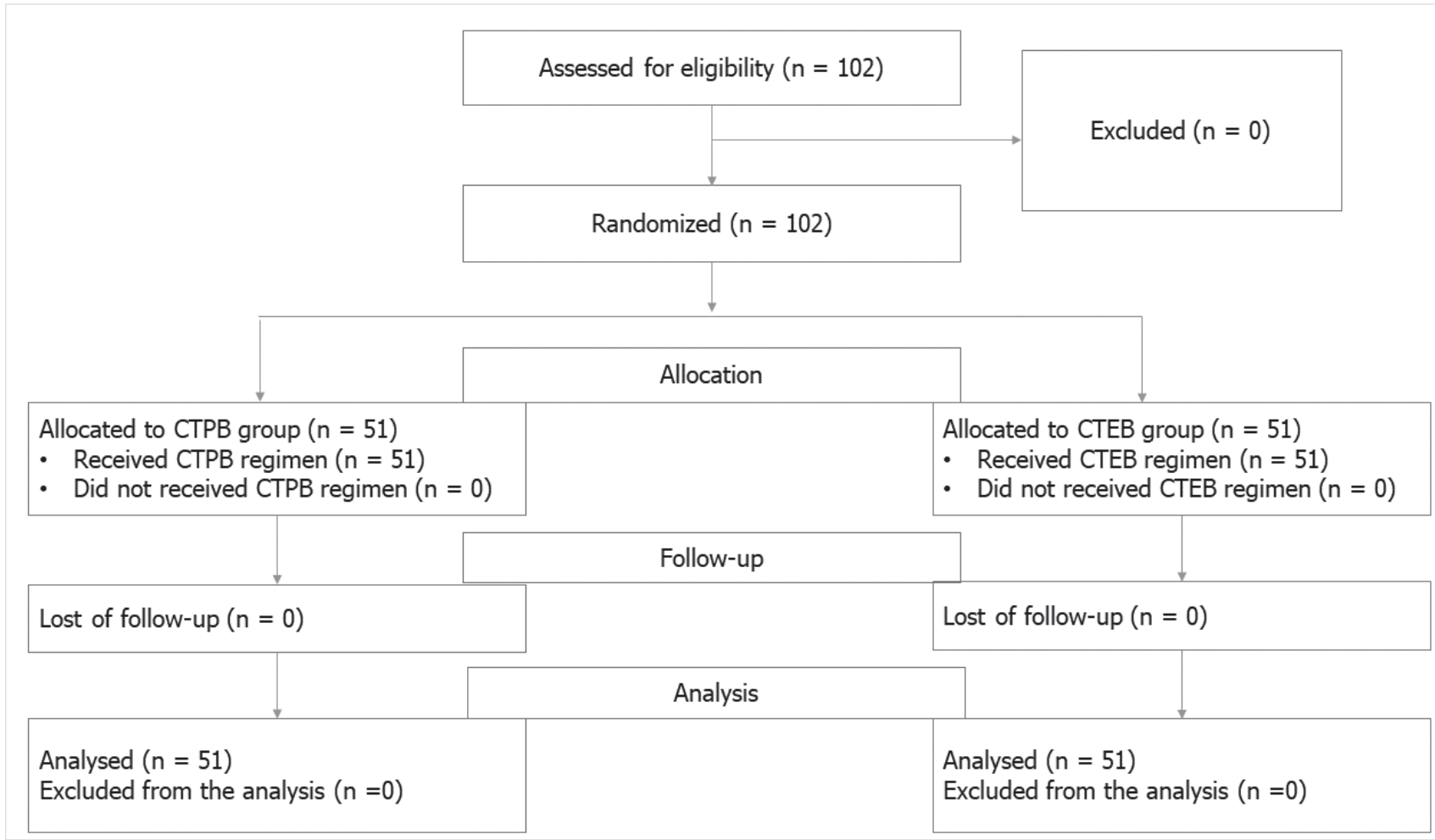

Figure 1. Patients enrollments followed CONSORT flow diagram. 
Table 1. The demographic and surgical characteristics of enrolled patients in two groups

\begin{tabular}{|c|c|c|c|}
\hline & CTPB $(n=51)$ & CTEB $(n=51)$ & $\mathrm{p}$ \\
\hline Age (years) & $48.8 \pm 16.2$ & $45.0 \pm 13.5$ & 0.205 \\
\hline Height (cm) & $161.8 \pm 7.1$ & $163.8 \pm 6.3$ & 0.135 \\
\hline Weight (kg) & $51.0 \pm 8.8$ & $52.68 \pm 8.8$ & 0.354 \\
\hline BMI $\left(\mathrm{kg} / \mathrm{m}^{2}\right)$ & $19.4 \pm 2.8$ & $19.6 \pm 2.7$ & 0.833 \\
\hline Male $(n, \%)$ & $44(86.3 \%)$ & $46(90.2 \%)$ & \multirow{2}{*}{0.539} \\
\hline Female (n, \%) & $7(13.7 \%)$ & $5(9.8 \%)$ & \\
\hline \multicolumn{4}{|l|}{ ASA score } \\
\hline I $(n, \%)$ & $7(13.7 \%)$ & $14(27.5 \%)$ & 0.087 \\
\hline$\|(n, \%)$ & $44(86.3 \%)$ & $37(72.5 \%)$ & \\
\hline \multicolumn{4}{|l|}{ Surgical procedure } \\
\hline Lung removal (n, \%) & $22(43.1 \%)$ & $20(39.2 \%)$ & 0.687 \\
\hline Lung decortication (n, \%) & $29(56.9 \%)$ & $31(60.8 \%)$ & \\
\hline \multicolumn{4}{|l|}{ Incision } \\
\hline Lateral thoracotomy $(\mathrm{n}, \%)$ & $47(92.2 \%)$ & $45(82.2 \%)$ & 0.084 \\
\hline Posterolateral thoracotomy (n, \%) & $4(7.8 \%)$ & $6(11.8 \%)$ & 0.851 \\
\hline Length of surgical skin incision (cm) & $24.9 \pm 4.2$ & $25.1 \pm 4.2$ & 0.353 \\
\hline
\end{tabular}

the normal range at the second postoperative date, which was earlier than patients in the CTPB group (at the third postoperative date). However, blood glucose levels were not significantly different between the two groups (Table 2). A similar trend was seen for blood cortisol levels. Except for a clear difference of blood cortisol level at the first postoperative date between the two groups ( $p=0.021$ ), this figure before the surgery and at other time points saw insignificant differences ( $p>0.05$ ). Nevertheless, at the third postoperative day, these levels in both groups were still remarkably higher than that before the surgery.

Before the surgery, ventilatory lung functions were similar between the two groups (Table 2). Nevertheless, patients in the CTPB group showed earlier recovery compared to the CTEB group, as shown by the visibly higher values of FVC, FEV ${ }_{1}$, and PEF of patients receiving CTPB regime compared to patients receiving CTEP regime.

Regarding undesirable effects relating to the anesthetic technique, the percentages of vascular puncture and pain at the injection site were lower in the CTPB group compared to the CTEB group, although they were not significantly different. Our study did not record any case of pneumothorax, catheter occlusions, or infection at the injection site in both groups.

The percentage of hypotensive cases in the CTPB group were significantly less than in the CTEB group (3.9\% vs 17.6\%, p= 0.026). Slow breathing and motor block in both legs accounted for $9.8 \%$ and $11.8 \%$ in the CTEB group, while no case was reported in the CTPB group.
The percentage of side effects relating to morphine analogues such as vomit, nausea, urinary retention, and itch was not statistically different between both groups, although there were lower frequencies in the CTPB group compared to the CTEB group.

\section{DISCUSSION}

Our findings showed that patients in the CTEB and the CTPB group had a significant reduction of pain level after 15 minutes of treating with pain regime, which meant both procedures were effective to relieve pain. The pain levels of patients in both groups were comparable in all time-points indicating that these procedures had comparable efficacy in the reduction of pain. Interestingly, patients in the CTPB group had fewer complications compared to patients in the CTEB group.

Although there was a randomized prospective trial in 2011 showing that TPB appeared to control pain well at rest and cough than TEB, other findings showed that the differences were not remarkably different (14). A systematic review and meta-analysis previously showed that the analgesic efficacy 48 hours after thoracotomy was comparable between TPB and TEB (15). Messina et al. (2009) have also reported that the pain relief was still not much different at 72 hours after surgery, as shown by the VAS scores at rest between the two groups. Moreover, the VAS scores after coughing were similar in the 24-hour period after surgery as the report of Sagiroglu et al. (2013). Our study increased the power of the comparable efficacy between two techniques, as we found out that the VAS scores at rest or at movement at all time-points during 72 hours after surgery were not statistically different. On the other hand, our results 
Table 2. Response to stress and ventilatory functions of the patients in two groups

\begin{tabular}{|c|c|c|c|c|}
\hline & Before the surgery & $\begin{array}{c}\text { The first postoperative } \\
\text { date }\end{array}$ & $\begin{array}{l}\text { The second } \\
\text { postoperative date }\end{array}$ & $\begin{array}{c}\text { The third postoperative } \\
\text { date }\end{array}$ \\
\hline \multicolumn{5}{|c|}{ Blood glucose $(\mathrm{mmol} / \mathrm{l})$} \\
\hline CTPB group $(n=51)$ & $5.7 \pm 1.0$ & $7.7 \pm 2.4^{*}$ & $6.7 \pm 1.4^{*}$ & $6.3 \pm 2.4$ \\
\hline CTEB group $(n=51)$ & $6.1 \pm 2.7$ & $7.4 \pm 3.1^{*}$ & $6.3 \pm 1.3$ & $5.9 \pm 1.3$ \\
\hline$p$ & 0.410 & 0.525 & 0.102 & 0.325 \\
\hline \multicolumn{5}{|l|}{ Blood cortisol ( $\mu \mathrm{g} / \mathrm{dl})$} \\
\hline CTPB group $(n=51)$ & $11.3 \pm 6.4$ & $19.6 \pm 6.6^{*}$ & $17.1 \pm 5.4^{*}$ & $15.6 \pm 4.8^{*}$ \\
\hline CTEB group $(n=51)$ & $12.0 \pm 5.7$ & $22.6 \pm 6.1^{*}$ & $17.5 \pm 5.3^{*}$ & $14.9 \pm 5.1^{*}$ \\
\hline$p$ & 0.521 & 0.021 & 0.732 & 0.503 \\
\hline \multicolumn{5}{|l|}{ FVC (I) } \\
\hline CTPB group $(n=51)$ & $2.78 \pm 0.94$ & $1.33 \pm 0.31^{*}$ & $1.83 \pm 0.56^{*}$ & $2.46 \pm 0.67^{* *}$ \\
\hline CTEB group $(n=51)$ & $2.88 \pm 0.73$ & $1.00 \pm 0.39^{*}$ & $1.50 \pm 0.44^{*}$ & $2.18 \pm 0.6^{*}$ \\
\hline $\mathrm{p}$ & 0.574 & 0.000 & 0.001 & 0.032 \\
\hline \multicolumn{5}{|l|}{$\mathrm{FEV}_{1}(\mathrm{I})$} \\
\hline CTPB group $(n=51)$ & $2.27 \pm 0.71$ & $0.68 \pm 0.22^{*}$ & $1.2 \pm 0.34^{*}$ & $1.86 \pm 0.60^{*}$ \\
\hline CTEB group $(n=51)$ & $2.42 \pm 0.61$ & $0.62 \pm 0.20^{*}$ & $0.94 \pm 0.33^{*}$ & $1.71 \pm 0.55^{*}$ \\
\hline $\mathrm{p}$ & 0.244 & 0.117 & 0.000 & 0.193 \\
\hline \multicolumn{5}{|l|}{ Gaensler (\%) } \\
\hline CTPB group $(n=51)$ & $82.5 \pm 12.54$ & $52.7 \pm 17.42^{*}$ & $67.9 \pm 19.56^{*}$ & $76.5 \pm 17.35^{* *}$ \\
\hline CTEB group $(n=51)$ & $85.2 \pm 9.44$ & $65.7 \pm 19.54^{*}$ & $63.4 \pm 20.08^{*}$ & $79.6 \pm 19.32^{* *}$ \\
\hline$p$ & 0.217 & 0.001 & 0.262 & 0.390 \\
\hline \multicolumn{5}{|l|}{ PEF (I) } \\
\hline CTPB group $(n=51)$ & $5.42 \pm 1.75$ & $1.18 \pm 0.25^{*}$ & $2.40 \pm 0.25^{*}$ & $4.27 \pm 0.82^{*}$ \\
\hline CTEB group $(n=51)$ & $5.82 \pm 1.6$ & $1.05 \pm 0.28^{*}$ & $1.83 \pm 0.19^{*}$ & $3.52 \pm 0.69^{*}$ \\
\hline $\mathrm{p}$ & 0.238 & 0.011 & 0.000 & 0.000 \\
\hline \multicolumn{5}{|c|}{$\begin{array}{l}\text { The data were shown as mean } \pm \text { SD. } \\
{ }^{*}<0.01 \text { compared to before the surgery. } \\
* * 0.05 \text { compared to before the surgery. }\end{array}$} \\
\hline
\end{tabular}

even showed that pain relief was significantly reduced after 15 minutes of the analgesic regime while the previous reports recorded at 2, 4, or 6 hours after treatment $(4,12,15)$. On the other hand, other studies used $0.25 \%$ bupivacaine, the mixture of $0.25 \%$ levobupivacaine and fentanyl $1.6 \mu \mathrm{g} / \mathrm{mL}$, or $0.45 \%$ ropivacaine for the analgesia $(4,12,16)$. Our analgesic regimen using the mixture of $0.125 \%$ bupivacaine and fentanyl $2 \mu \mathrm{g} / \mathrm{mL}$ showed the similar efficacy that the pain levels reduced to mild in patients of both groups.

Postoperation often sees the elevation of cortisol and glucose levels, as they are signals of surgical trauma and stress. These levels could be regulated by the analgesic regimens, therefore, they were often used to assess the efficacy of pain relief after the surgery $(17,18)$. Differing from the results of Gulbahar et al. (2010) who saw that only glucose blood levels notably increased after the thoracotomy, our results showed that both the blood glucose and blood cortisol levels after the surgery strongly increased compared to normal conditions, and were much higher than that before the surgery. These results indicated that patients in our study suffered stress response after lung removal or lung decortication, as these procedures could cause extremely severe pain. Nevertheless, our results were in line with this study in which postoperative levels of blood glucose and blood cortisol were not different between the two groups on the first date after regimens.

Interestingly, our results found that a significant difference happened on the second postoperative day between the two groups when the blood glucose level in the CTEB group was not remarkably different from the day before surgery. Till the third operative day, the blood glucose concentration of patients in CTPB was indifferent from the date before the surgery. Moreover, although blood cortisol levels were insignificantly different be- 
Table 3. VAS score at rest $\left(V_{R}\right)$ and at movement $\left(V_{M}\right)$ between the two groups

\begin{tabular}{|c|c|c|c|c|c|c|}
\hline \multirow[b]{2}{*}{ Time } & \multicolumn{3}{|c|}{$V_{R}$} & \multicolumn{3}{|c|}{$\mathrm{v}_{\mathrm{M}}$} \\
\hline & $\begin{array}{l}\text { CTPB group } \\
(n=51)\end{array}$ & $\begin{array}{l}\text { CTEB group } \\
\quad(n=51)\end{array}$ & $p$ & $\begin{array}{c}\text { CTPB group } \\
(n=51)\end{array}$ & $\begin{array}{l}\text { CTEB group } \\
\quad(n=51)\end{array}$ & $p$ \\
\hline $0-\min$ & $6.9 \pm 1.4$ & $6.5 \pm 1.2$ & 0.178 & $8.0 \pm 1.2$ & $7.8 \pm 1.1$ & 0.276 \\
\hline 15-min & $3.5 \pm 1.0^{*}$ & $3.5 \pm 0.9^{*}$ & 1.000 & $4.8 \pm 0.9^{*}$ & $4.4 \pm 0.9^{*}$ & 0.056 \\
\hline 30-min & $2.9 \pm 0.8^{*}$ & $3.1 \pm 0.7^{*}$ & 0.237 & $3.9 \pm 0.9^{*}$ & $3.7 \pm 0.7^{*}$ & 0.201 \\
\hline 1-hour & $2.7 \pm 0.6^{*}$ & $2.7 \pm 0.5^{*}$ & 0.724 & $3.6 \pm 0.8^{*}$ & $3.6 \pm 0.7^{*}$ & 1.000 \\
\hline 2-hours & $2.6 \pm 0.6^{*}$ & $2.7 \pm 0.8^{*}$ & 0.483 & $3.4 \pm 0.6^{*}$ & $3.4 \pm 1.0^{*}$ & 0.731 \\
\hline 4-hours & $2.6 \pm 0.6^{*}$ & $2.5 \pm 0.6^{*}$ & 0.746 & $3.1 \pm 0.6^{*}$ & $3.2 \pm 0.9^{*}$ & 0.315 \\
\hline 6-hous & $2.5 \pm 0.9^{*}$ & $2.4 \pm 0.6^{*}$ & 0.286 & $3.1 \pm 1.1^{*}$ & $3.0 \pm 0.7^{*}$ & 0.467 \\
\hline 12-hours & $2.1 \pm 0.6^{*}$ & $2.2 \pm 0.6^{*}$ & 0.532 & $2.6 \pm 0.8^{*}$ & $2.6 \pm 0.8^{*}$ & 0.715 \\
\hline 24-hours & $1.9 \pm 0.5^{*}$ & $2.0 \pm 0.7^{*}$ & 0.197 & $2.4 \pm 0.5^{*}$ & $2.5 \pm 0.6^{*}$ & 0.404 \\
\hline 48-hours & $1.6 \pm 0.6^{*}$ & $1.7 \pm 0.7^{*}$ & 0.550 & $2.1 \pm 0.6^{*}$ & $2.3 \pm 0.6^{*}$ & 0.216 \\
\hline 72-hours & $1.4 \pm 0.8^{*}$ & $1.5 \pm 0.8^{*}$ & 0.607 & $2.0 \pm 0.6^{*}$ & $2.0 \pm 0.5^{*}$ & 0.553 \\
\hline
\end{tabular}

tween the two groups on all studied days, these values were still much higher than before the surgery in both groups indicating that the stress response had not been very well controlled.

Two of the criteria used to evaluate the analgesic efficacy are the percentage of patients needing additional analgesic intervention, and the total dose of morphine. Although Sagiroglu et al. (2013) have revealed that the total additional dose of morphine after 24 hours in the PB group was higher than in the EP group, no significant differences were determined $(p=0.056)$. Gulbahar et al. (2010) have shown that the times that patients ordered additional morphine sulfate between the two groups at the first, the second, and the third postoperative date were not significantly different. Our results were concordant with these previous reports which supported the similar efficacy between the two groups.

The worst pain after thoracic surgery is an important cause of poor ventilation efficiency and restricted cough, which affects long and deep breathing. Effective pain management would reduce the failure of lung functions, or sometimes would reverse them and prevent postoperative complications. Our results showed that after surgery, lung functions were impaired remarkably compared to that before the surgery $(p<0.01)$. The recovery of these ventilatory functions after surgery in the CTPB group was better than the CTEB group, as shown by the significantly higher values of FVC and PEF at all studied days. FEV values of CTPB groups were also higher than in CTEB groups, although they were not significantly different. These results were in line with another report indicating the decreased lung volume 4 hours after the surgery observed in both PB and EB groups (19). The patients in this study who received the analgesic regimen with $\mathrm{PB}$ showed better improvement than patients in the EP group as well. The results might be attributed to the sole affection on the operated lung of the PB that did not cause any impairment of another lung's functions.

Regarding undesirable effects, PB only blocks the sympathetic on one side resulting in lower percentages of hypotensive patients receiving PB regimen when compared to the EP. Many studies have indicated similar results that patients in the PB group had a smaller percentage of complications of hypotension than patients in the EP group (20-22). Only Huyen (2017) has reported that the difference was not statistically different between the two procedures $(p=0.48)$. Our study revealed that the hypotension was not very serious amongst the patients. The patient with the lowest blood pressure by $86 \mathrm{mmHg}$ only needed a faster speed of the infusion, but no requirement of ephedrine.

We recorded that motor block in both legs was only observed in patients in the CTEB group. This proved that the anesthetic medicines covered all nerve roots inside the pleural space and spread across the underneath levels which resulted from the diffusion of the anesthetic medicines to the pleural space after the injection. On the other hand, because of the continuous injection of anesthetic medicines into the epidural space, the medicines could partly diffuse to the cerebrospinal fluid via the epidural space. In our study, no case had anesthesia in the complete spinal cord, anesthesia in epidural when conducting the PB intervention, or the toxicity relating to anesthesia.

The frequency and the serious degrees of the undesirable effects relating to the anesthesia, for example, vascular puncture and pain at the injection site, were also lower in the PB group than the EP group, although they were not significant. This advantage might be due to the ultrasound-guided technique that benefited the surgeons to determined anatomical points. This result was also similar to the report of Naja and Longqvist (23). 
The most popular side effects in our study were vomitting and nausea caused by morphine analogues. Despite they were not dangerous, they caused discomfort in patients after the surgery. For urinary retention, a lower frequency was observed in the CTPB group than the CTEB group because PB blocks the motor nerve which affects one side of the body, resulting in the available bladder sensation.

In our study, we used ultrasound to support the CTPB because it increased the accuracy of surgical manipulation and the safety of the surgery. Ultrasound helps surgeons determine the vertebra, the pulmonary pleura, the thoracic paravertebral space, the distance between skin and the vertebra, the distance between skin and the pulmonary pleura, the distance between skin and thoracic paravertebral space. Also, it is possible to detect the movement of the needle, confirm the presence of the needle or catheter in the thoracic paravertebral space. All those gains of ultrasound-guided CTPB improved the efficacy and safety of the procedure (24-27). Bakshi et al (2017) have also supposed that this procedure was valuable to manage postoperative pain, especially after one-side surgeries (27). Some complications including pleural perforation, pneumothorax could be avoided in the ultrasound-guided CTPB. Besides, ultrasound-guided CTPB also reduces the number of needle pokes and helped place catheter properly (28). These suggestions were also observed in our study.

Taken all together, we realized that PB had a good effect on pain management after the surgery. Its efficacy was comparable to EP (a gold standard for postoperative analgesia after thoracic surgery). On top of that, CTPB under ultrasound-guidance using bupivacaine - fentanyl also had a smaller percentage of side effects. Patients receiving this regimen had fewer pulmonary complications and recovered the ventilatory functions better Our results are expected to reinforce the current findings and provide clinicians with more evidence to apply this technique.

Our limitation includes a small eligible patients delivering to our hospital that made the study prolonged. The sample was collected at only one hospital that could not represent to Vietnamese population and population in other countries as a whole. In addition, the assessment of VAS scores might be subjective and have affected the precision of the results. We recommend a study of multiple centers being conducted to confirm the effects.

\section{CONCLUSION}

Ultrasound-guided CTPB has a good effect on pain relief after lung surgery. Its efficacy was comparable to the EP, and the undesirable effects on the circular system, respiratory system were less than EP. The percent of side effects in patients using bupivacaine - fentanyl was low. It also did not lead to any dangerous complications. Ultrasound-guided CTPB could replace the EP for postoperative anesthesia, especially when EP is contraindicated or failed.

Ethics Committee Approval: The study was obtained from 74 Central Hospital Bromedical Studies Ethics Committee (No: 458/GCN-BV74TW).
Peer-review: Externally peer-reviewed.

Author Contributions: Concept -T.T.T., T.V.D.; Design - T.T.T.; Supervision -T.V.D.; Materials - All of authors; Data Collection and/or Processing - T.T.T.; D.V.K.; Analysis and/or Interpretation - T.T.T.; D.V.K.; Literature Search- T.T.T.; D.V.K.; Writing Manuscript -T.T.T.; D.V.K.; Critical Reviews - T.T.T.

Conflict of Interest: The authors have no conflicts of interest to declare.

Financial Disclosure: The authors declared that this study has received no financial support.

\section{REFERENCES}

1. Tu NH. Anesthesia for thoracic surgery (Lession of Anesthesia and Resuscitation). Vietnam: Medicine Publisher; 2002. [CrossRef]

2. Attri JP, Kaur R, Kaur H. Post thoracotomy pain management: A review of current available modalities. Northern Journal of ISA 2016; 1: 7-10. [CrossRef]

3. Cucu O, Karaca K, Enc Y, Camur G, Yurtseven N, Okay T, et al. Comparison of epidural anesthesia and paravertebral nerve block in patients undergoing thoracotomy. Internet J Anesthesiol 2005; 11(1): 1-8. [CrossRef]

4. Messina M, Boroli F, Landoni G, Bignami E, Dedola E, N'Zepa Batonga J, et al. A comparison of epidural vs. paravertebral blockade in thoracic surgery. Minerva Anestesiol 2009; 75(11):616-21. [CrossRef]

5. Lonnqvist PA, MacKenzie J, Soni AK, Conacher ID. Paravertebral blockade. Failure rate and complications. Anaesthesia 1995; 50(9): 813-5.

6. Richardson J, Lonnqvist PA. Thoracic paravertebral block. Br J Anaesth 1998; 81(2): 230-8. [CrossRef]

7. Ultrasound-guided thoracic parvertebral blocks: anatomy, approac hes and techniques [Internet]. American Society of Regional Anesthesia and Pain Medicine 2012. Available from: https://pdfs.semanticscholar.org/8b5d/40e72d0bd92cf3a74a099b2248d279a6d8bf.pdf. [CrossRef]

8. Pace MM, Sharma B, Anderson-Dam J, Fleischmann K, Warren L, Stefanovich P. Ultrasound-guided thoracic paravertebral blockade: A retrospective study of the incidence of complications. Anesth Analg 2016; 122(4): 1186-91. [CrossRef]

9. Reisig F, Buttner J. Ultrasound-guided thoracic paravertebral block for acute thoracic trauma: continuous analgesia after high speed injury. Anaesthesist 2013; 62(6): 460-3. [CrossRef]

10. Norum HM, Breivik H. A systematic review of comparative studies indicates that paravertebral block is neither superior nor safer than epidural analgesia for pain after thoracotomy. Scand J Pain 2017; 1(1): 12-23. [CrossRef]

11. Vietnam Ministry of Health. Determination of sample size in health studies: Medicine Publisher; 2007. 57-64 p. [CrossRef]

12. Sagiroglu G, Baysal A, Copuroglu E, Karamustafaoglu YA, Sagiroglu $T$, Yuksel $V$, et al. The efficacy of thoracic epidural and paravertebral blocks for postthoracotomy pain management. Polish Journal of Cardio-Thoracic Surgery 2013; 2: 139-48. [CrossRef]

13. Tim S, Colin P, Ted L. Fundamentals of Anaesthesia. 3rd ed:Cambridge University Press; 2009. [CrossRef]

14. Raveglia F, Rizzi A, Leporati A, Di Mauro P, Cioffi U, Baisi A. Analgesia in patients undergoing thoracotomy: epidural versus paravertebral technique. A randomized, double-blind, prospective study. J Thorac Cardiovasc Surg 2014; 147(1): 469-73. [CrossRef]

15. Junior AP, Erdmann TR, Santos TV, Brunharo GM, Filho CT, Losso MJ, et al. Comparison between continuous thoracic epidural and paravertebral blocks for postoperative analgesia in patients undergoing thoracotomy: Systematic review. Brazil J Anesthesiol 2013; 63(5): 433-42. [CrossRef] 
16. Gulbahar G, Kocer B, Muratli SN, Yildirim E, Gulbahar O, Dural K, et al. A comparison of epidural and paravertebral catheterisation techniques in post-thoracotomy pain management. Eur J Cardiothorac Surg 2010; 37(2): 467-72. [CrossRef]

17. Kouraklis G, Glinavou A, Raftopoulos L, Alevisou V, Lagos G, Karatzas GJls. Epidural analgesia attenuates the systemic stress response to upper abdominal surgery: a randomized trial. 2000; 85(4): 353-7. [CrossRef]

18. Friedrich M, Rixecker D, Friedrich GJC. Evaluation of stress-related hormones after surgery. Obstetrics Gynecol 1999; 26(2):71-5. [CrossRef]

19. Zorob AAF, Nassar MA, El-Said T. Paravertebral and epidural blocks for post thoracotomy pain. Egypt J Hosp Med 2001; 3: 21-5. [CrossRef]

20. Huyen DK. Comparison of the analgesic efficacy and the safety between the continuous the thoracic paravertebral block and the continuous thoracic epidural block after the removal of a part of lung. Conference of Science and Technology at University of Medicine and Pharmacy at Ho Chi Minh City 2017. [CrossRef]

21. Kumar TS, Rajendran R. Comparative evaluation of thoracic epidura rersus thoracic paravertebral block for post thoracotomy pain relief with 0,25 bupivacain. Indian J Anaesth 2003; 47(4): 269-74. [CrossRef]

22. Kosinski S, Fryzlewicz E, Wilkojc M, Cmiel A, Zielinski M. Comparison of continuous epidural block and continuous paravertebral block in postoperative analgaesia after video-assisted thoracoscopic surgery lobectomy: a randomised, non-inferiority trial. Anaesthesiol Intensive Ther 2016; 48(5): 280-7. [CrossRef]
23. Naja Z, Lonnqvist PA. Somatic paravertebral nerve blockade. Incidence of failed block and complications. Anaesthesia 2001; 56(12): 11848. [CrossRef]

24. Pawa A, Wojcikiewicz T, Barron A, El-Boghdadly K. Paravertebral blocks: anatomical, practical, and future concepts. Curr Anesthesiol Rep 2019; 9(3): 263-70. [CrossRef]

25. Cadavid-Puentes AM, Casas-Arroyave FD, Palacio-Montoya LM, Valencia-Gallón E. Efficacy of paravertebral block techniques in thoracic surgery: systematic literature review. Rev Esp Anestesiol 2020; 48(1): 20-9. [CrossRef]

26. Abrahams $M$, Derby $R$, Horn J-L. Update on ultrasound for truncal blocks: a review of the evidence. J Regional Anesthesia Pain Medicine 2016; 41(2): 275-88. [CrossRef]

27. Bakshi S, Karan N. Ultrasound-guided paravertebral block: A valuable armamentarium for post-operative pain management. Indian J Anaesth 2017; 61(2). [CrossRef]

28. Varughese SA, Bharti SJ, Kumar V. Intrapleural migration of paravertebral catheter in spite of ultrasound guidance. Lung India 2017; 34(3): 295. [CrossRef]

\section{ORIJINAL ÇALIŞMA-ÖZET}

Turk J Surg 2021; 37 (3): 232-241

\section{Akciğer cerrahisi geçiren hastalarda ultrason eşliğinde sürekli torasik paravertebral blok ile bupivakain-fentanil kullanan sürekli torasik epidural blok arasındaki analjezik etkinliğin karşılaştırılması: Prospektif, randomize, kontrollü bir çalışma}

Tran Thanh Trung ${ }^{1}$, Dang Van Khoa ${ }^{1}$, Trinh Van Dong ${ }^{2}$

174 Central Hastanesi, Anestezi ve Reanimasyon Kliniği, Vinh Phuc, Vietnam

${ }^{2}$ Viet Duc Üniversitesi Hastanesi, Anestezi ve Reanimasyon Anabilim Dalı, Hanoi, Vietnam

\section{ÖZET}

Giriş ve Amaç: Bu çalışmanın amacı, akciğer cerrahisi yapılan hastalarda ağrı yönetimi için kullanılan ultrason rehberliğinde sürekli toraksik paravertebral blok (CTPB) ile sürekli toraksik epidural blok (CTEB) yöntemlerinin etkinliği ve güvenirliliğini karşılaştırmaktı.

Gereç ve Yöntem: Çalışmaya, Eylül 2013 ve Aralık 2017 tarihleri arasında 74 Central Hastanesi'nde akciğer cerrahisi uygulanan 102 hasta dâhil edildi. Hastalar iki gruba ayrıldı: CTPB grubu $(n=51)$ ve CTEB grubu $(n=51)$. Birincil sonuçlar, hastalar dinlenme $\left(V_{R}\right)$ ve hareket $\left(V_{M}\right)$ halindeyken ölçülen Vizüel Analog Skala (VAS) skorları ile operasyon sonrası kullanılan toplam bupivakain-fentanil dozu, plazma glikoz ve kortizol seviyeleri ve ek morfin dozlarıydı. Çalışma süresince advers reaksiyonlar kaydedildi. Çalışma, 74 Central Hastanesi Etik Kurulu tarafından onaylandı. Tüm hastalardan bilgilendirilmiş onam alındı.

Bulgular: CTPB ve CTEB grupları arasında $V_{R} v e V_{M^{\prime}}$ cerrahi sonrası 72. saatte kullanılan toplam bupivakain - fentanil dozu $(p>0,05)$, artmış plazma glikoz, plazma kortizol $(p>0,05)$ ve ek morfin dozları açısından anlamlı bir fark yoktu. CTPB grubundaki hastaların dolaşım ve solunum sisteminde advers reaksiyonlar görülme oranı CTEB grubundakilere kıyasla daha düşüktü. Advers reaksiyonlar, vasküler ponksiyonu, idrar tutma ve kaşınma isteği idi.

Sonuç: Ultrason rehberliğinde CTPB, akciğer cerrahisi sonrası ağrı yönetiminde etkin bir müdahale şeklidir. Analjezik etkinliği CTEB'ninkine benzemektedir. Ayrıca, CTEB'ye kıyasla bu yöntem dolaşım ve solunum sisteminde daha az advers reaksiyona sebep oldu.

Anahtar Kelimeler: Paravertebral blok, analjezi, akciğer cerrahisi, epidural blok, postoperatif ağıı 
242 Comparison between CTPB and CTEB 